\title{
The continuum of coal violence and post-coal possibilities in the Appalachian South
}

\author{
Erin R. Eldridge ${ }^{1}$ \\ Fayetteville State University, USA
}

\begin{abstract}
From the coalfields in the mountains to the coal-fired power stations scattered throughout the region, the coal economy has long shaped landscapes and livelihoods in the Appalachian South. This article combines the "continuum of violence" framework developed by Scheper-Hughes and Bourgois (2004) with a political ecological approach to examine at the multiple dimensions of violence associated with the coal economy in the Appalachian South. Drawing on insights from fieldwork and the history of coal in the region, this article specifically examines the socio-political arrangements, perverse economic incentives, and legitimation strategies at the heart of the blatant, symbolic, and structural forms of violence that manifest all along the 'social life' of coal. There has always been much more to this popularly misunderstood region than coal, however. As a number of anthropologists working in the region recently noted, Appalachia also has a long history of activism, solidarity networks, mutual aid traditions, and non-market subsistence strategies. To conclude, some of the possibilities emerging out of current crises of the coal economy are discussed.
\end{abstract}

Keywords: extraction, coal economy, coal ash, socio-ecological violence, political ecology, Appalachia

\section{Résumé}

Les paysages et les moyens de subsistance dans les Appalaches du Sud sont façonnées par une économie de charbon. Il comprend les mines de charbon dans les montagnes et les centrales électriques au charbon dispersés dans toute la région. Cet article combine le cadre de «continuum de violence» développé par Scheper-Hughes et Bourgois (2004) avec l'écologie politique pour examiner les multiples dimensions de la violence associés à l'économie du charbon dans les Appalaches du Sud. Puisant aux connaissances de terrain et l'histoire du charbon dans la région, l'article examine spécifiquement les arrangements socio-politiques, incitations économiques perverses, et les stratégies de légitimation au cœur des formes flagrantes, symboliques et structurelles de la violence qui se manifestent tout au long de la «vie sociale» du charbon. Mais il a toujours été beaucoup plus que le charbon dans cette région méconnue. Comme un certain nombre d'anthropologues travaillant dans la région a récemment noté, les Appalaches a également une longue histoire d'activisme, des réseaux de solidarité, les traditions d'entraide, et les stratégies de subsistance non marchands. Pour conclure, cet article souligne quelques-unes des possibilités qui émergent des crises actuelles de l'économie de charbon.

Mots-clés: l'extraction, l'économie de charbon, la cendre de charbon, la violence socio-écologique, l'écologie politique, les Appalaches

\section{Resumen}

Desde los yacimientos de carbón en las montañas hasta las estaciones eléctricas de carbón dispersas a lo largo de la region, la economía del carbón ha moldeado los paisajes y medios de sustento al sur de los Apalaches. Este artículo combina la propuesta "continuo de violencia" desarrollada por Scheper-Hughes y Bourgois (2004) con una aproximación desde la política ecológica para examiner las múltiples dimensiones de la violencia asociada con la economía del carbón al sur de los Apalaches. Basado en datos de campo y la historia del carbón en la región, este artículo específicamente examina los acuerdos socio-políticos, incentivos económicos perversos, y las estrategias de legitimización en el corazón de las formas de violencia descaradas, simbólicas, y estructurales que se manifiestan a los largo de la 'vida social' del carbón. Sin

\footnotetext{
${ }^{1}$ Dr. Erin R. Eldridge, Assistant Professor of Anthropology, Department of Sociology, Fay etteville State University, Fayetteville, NC 28301, USA. Email: eldridge.erin "at" gmail.com. I would like to express my gratitude to the JPE editors and anonymous reviewers for their valuable comments and suggestions.
} 
embargo, siempre ha habido mucho más que carbón en ésta región incomprendida popularmente. Tal como un grupo de antropólogos trabajando en la región notaron recientemente, los Apalaches también tienen una larga historia de activismo, redes de solidaridad, tradiciones de ayuda mutua, y estrategias de subsistencia fuera del mercado. En conclusión, se discuten algunas de las posibilidades que emergen de la crisis actual de la economía del carbón.

Palabras clave: extracción, economía del carbón, cenizas de carbón, violencia socio-ecológica, ecología política, Apalaches

\section{Introduction}

Coal, as a key fuel for industrialization, was once hailed as a means through which humans could free themselves from nature and enter a world of unending progress and growth. The success of the industrial revolution, as noted by Weber (quoted in Foster and Holleman 2012: 1646), was a result of the "fateful union of iron and coal", and to many $19^{\text {th }}$ and early $20^{\text {th }}$ century writers, scientists, and businessmen, coal not only represented humanity's victory over nature, but also a means for controlling "our own savage human nature" (Freese 2004: 8-13). Coal has long played a pivotal role in social and economic development efforts to 'modernize' the Appalachian South, and the drive to produce coal has fundamentally altered human relationships with the environment in very destructive ways. ${ }^{2}$

While discussing John Peter Salling, the man credited for discovering coal in West Virginia in 1742, the late mountain activist Judy Bonds, remarked, "If he had known what agony it would have caused, he'd have covered it up and kept his mouth shut" (Geller 2009). The multidimensionality of this 'agony' is the focus of this article. Drawing on the historical literature on coal catastrophes in the region, as well as research on coal ash and the politics of coal, this article combines a political ecological approach with the "continuum of violence" framework developed by Scheper-Hughes and Bourgois (2004) to highlight the blatant, symbolic, and structural forms of violence that manifest along the social life of coal. In an effort to avoid the pitfalls of a capitalocentric critique (Burke and Shear 2014) or what Fergus on (2009) calls the politics of "the antis", this article concludes by pointing to some of the possibilities emerging out of current crises of the coal economy.

\section{Dimensions of violence and the 'social life' of coal}

Violence is a complex phenomenon that, as Scheper-Hughes and Bourgois (2004: 2) observe, is not easily categorized. It is context specific and bound up with extensive and wide-ranging power relations and political economic processes. It can be a physical act of aggression or a subtle assault on dignity. Depending on the perspective, acts of violence may be denounced or glorified. This article emp loys the term broadly and recognizes that violence encompasses a multitude of ideas, acts, and practices that cause harm.

While violence is most commonly associated with direct force and blatant aggression, the physicality of violence is, as Bourgois (2009: 17) states, "merely the tip of the iceberg." Violence also occurs at more tacit levels and its lack of tangibility facilitates its reproduction within the social order. But if we "step back" and "disentangle ourselves from the fascinating lure" of visible violence, as Žižek (2008: 1-2) suggests, we are better positioned to recognize the less visible forms of structural and symbolic violence embedded in "the normal" state of things. This essay seeks to link the production and use of coal to various forms of violence that manifest over time, in geographic places, through policy processes, and by means of knowledge production. The violence continuum framework flexibly explores the often overlapping dimensions of violence that include not only the physical and obvious, but also the "little violences" produced in everyday life and conducted in "normative social spaces" (Scheper-Hughes and Bourgois 2004: 19).

Focusing on the symbolic aspects of social relations, Bourdieu believed that in some societies, the primary mode of domination is no longer direct coercion and force, but rather symbolic power, which he

\footnotetext{
${ }^{2}$ Following other Appalachian scholars (Cavender 2003: 7; Rehder 2004), 'Appalachian South' in this paper draws on a combination of political, physical, and cognitive maps of the region that includes areas designated as 'central' and 'southern' Appalachia by the Appalachian Regional Commission. Put more simply, it includes the areas where the broader Appalachian region overlaps with the Southeast, which also overlaps significantly (but not entirely) with the Tennessee Valley (see Figure 1).
} 
described as "a power of constructing reality" (Bourdieu 1991: 166). To Bourdieu, symbolic systems have a political function as instruments of domination and the legitimation of domination. "Symbolic violence", which can manifest through discourse, ideology, and stereotypes, normalizes hierarchical rankings, distinctions, and ideas of inclusion and exclusion (Bourdieu and Wacquant 2004; Swartz 1997).

Structural, or systemic, violence refers to the injustices embedded in the social order that limit life chances, such as unequal access to resources and decision-making power (Galtung 1969: 171). It is, Žižek (2008: 2) states, the "often catastrophic consequences of our economic and political systems." This type of violence, as Farmer (2004) reminds us, can reveal itself in the form of wealth disparities, illness, and disease. Uncovering the "subtle forms of coercion that sustain relations of do mination and exploitation", according to Žižek (2008: 2-13), is key to understanding the disruptive manifestations of direct, physical violence. Observable violence, in other words, can only be properly grasped in relation to the more abstract and historically rooted forms of "symbolic" and "systemic" violence.

This article additionally incorporates a perspective on violence that recognizes the mutuality, or coconstitution, of humans and the biophysical world. Because political economic systems, as stated by Watts and Peluso (2001: 5, 25), "have as their foundation the transformation of nature in social, historical, and culturally informed ways", political ecology, as an analytical tool, is thus well suited to examine socioecological violence, which looks at the forms of social violence described above in relation to the environment. Understanding socio-ecological violence requires investigation into local histories, resource environments, and ideological phenomena (Peluso and Watts 2001). It requires examining the political economic processes that shape access and control over resources, as well as the material practices that produce not only explosive and abrupt violence, but also the "slow violence" of industrial contaminants that take shape in our bodies and ecosystems (Nixon 2011).

The following sections trace the 'social life' of coal from extraction to combustion to uncover the interweaving forms of violence produced throughout Appalachia's coal economy. Commodities, such as coal, are not simply material objects of exchange; they are materially and socially produced. Commodities have biographies and following their life histories can "make salient what might otherwise remain obscure" (Kopytoff 1986: 67). Tracing the social life of coal, therefore, can illuminate the socio-political and economic relations that produce violence along coal's trajectory.

\section{The violence of extraction}

This 'cradle to grave' analysis of coal's social life begins in the coal-producing mountains of the Appalachian South (Figure 1). The blatant forms of violence associated with coal extraction are well known, but beneath the explosions, fires, and labor struggles lie more subtle forms of violence that manifest through discourses and policy processes. This section illuminates the multiple layers of socio-ecological violence associated with coal production in a widely misunderstood region.

\section{Constructing a land and a people}

Through the eyes of mainstream America, the Appalachian South has long been mythologized. The region is well known for its rural landscapes, poverty, and coal mining. Once deemed the "Other A merica" (Harrington 1962; Sarnoff 2003), it is too often considered the backwards counterpart of American modernity. Rooted in the religious, scientific, and philosophical discourses of $17^{\text {th }}$ and $18^{\text {th }}$ century Europe, ideas of modernity embody a world where humanity moves along a linear trajectory of development from 'traditional' to 'modern' and where nature-society relationships are in opposition. Nature is seen as something to be conquered and controlled for human benefit and self-realization (Bankoff 2004; Oliver-Smith 2004). Illustrating this sentiment, one European-born industrialist operating in Appalachia once exclaimed, "I realized as never before how powerful and dominant is man and that his mind could sway and use the giant force of nature" (Gaventa 1980: 62).

Early travel writers, entrepreneurs, and developers of Appalachia believed socio-economic transformation of the region required tapping the wealth of resources through the 'commercial spirit' of industry. "Lying in the heartland of the South", as historian Ron Eller (1982: 41) explained, "the mountains harbored the materials necessary for building a 'new civilization' - a New South constructed from the ashes 
of the old, but patterned in a more modern industrial mold." The aims of industrial modernity were to tame nature and convince the backwoods inhabitants of "the error of their ways" (Gaventa 1980: 70).

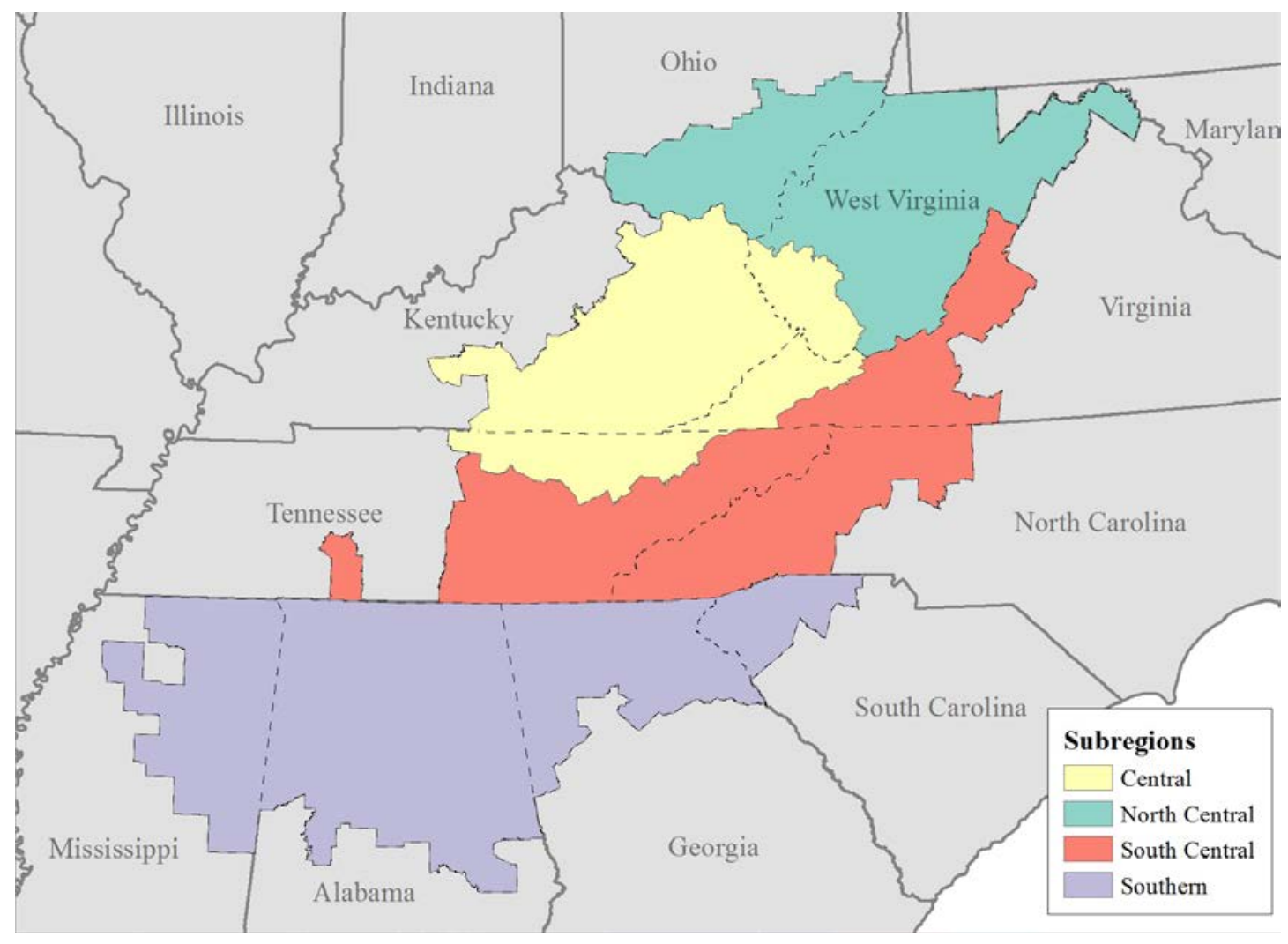

Figure 1: ARC Subregions in the South. Source: map adapted from the Appalachian Regional Commission (ARC 2009).

Modernization narratives are thus deeply interwoven with the history of coal and at the heart of Appalachian stereotypes. Stuart Hall (1997: 259) once described stereotyping as "a key element" in the "exerc ise of symbolic violence", noting how power is not simply exerted by force, but how it also "produces new discourses, new kinds of knowledge ... it shapes new practices ... and institutions." The practice of stereotyping, he explained (1997: 261), is a means of maintaining the social order in the context of great inequalities. It reduces people to essentialized, static categories for divisive purposes and thus constructs the excluded "other" (Hall 1997: 257-259).

For decades, the stereotypes of the Appalachian South have received much attention by scholars of the region. The cycle of degrading and romanticized myths that weave in and out of the national eye perpetually call for mo re nuanced counter-narratives. There is not space here to recapture all of these counter-discourses, but an investigation into the violence of coal must consider the assaults that occur consciously and unconsciously within the realm of the symbolic, and how they are entangled with the social and material processes that give rise to forms of structural and physicalviolence.

In Back Talk from Appalachia, Ledford (1999) analyzes early exploration and travel narratives in the region, making connections among economic concerns and representations of mountains and early settlers. The origins of Appalachian stereotypes, she argues, are intimately tied to the commodification of the mountains. From roughly the mid $17^{\text {th }}$ to the mid $18^{\text {th }}$ century, the colonial government sponsored explorations into the mountains in an attempt to alleviate tensions among different social groups and classes in coastal towns. To the early European explorers, it was the physical terrain of the mountains that first represented an ominous barrier to the imagined promises of the Western frontier. Explorers considered the 
mountains a dangerous, cruel, and inhospitable landscape with a hostile indigenous population (Ledford 1999: 48-55).

When the economic potential of the mountains was later realized, the landscape was no longer demonized as an obstacle to expansion. Rather, valorizing the wealth of the mountain lands became the desirable end goal, and the early mountain settlers became the new obstacles to that wealth. Ledford states, "Descriptions of backwoods people reflect growing concerns about socio-economic boundaries. The result is a first step toward the hillbilly stereotype, a characterization that has, on one level, been used to justify economic exploitation of the mountains and mountaineers for over two hundred years" (1999: 55).

The displacement of indigenous populations opened the Appalachian frontier to a wide variety of settlers and entrepreneurs, including small-scale farmers and herders, the elite planters and professional classes, large land holding companies, and later, large extractive industries (Pudup et al. 1995). With sustained settlement and increased travel through the region during the $19^{\text {th }}$ century, negative stereotypes of more remote settlers persisted among travel writers. In the late $19^{\text {th }}$ century, the region attracted writers of a genre referred to as 'local color.' Initially, Beaver (1988: 16) explains, Appalachia was represented "in terms of romantic wonder", but gradually "this wonder became distress about the imagined degradation and degeneracy observed in the mountains." The misrepresentations became "fact through American fiction."

These fictions, deeply bound up with rural landscapes, recur in a wide variety of contexts (Jarosz and Lawson 2002). Descriptions of the "illiterate" "unruly" Appalachian, "ill suited to make decisions for themselves" have been employed by public officials, environ mental organizations, and developers to displace thousands of people from valleys, hills, and mountains to establish park systems and large-scale hydroelectric projects (McDonald and Muldowny 1982; Powell 2007: 9; Weaver 1996). As Appalachia became "a magnificent field for capitalists" (Eller 1982: 53) with interests in what Weaver (1996) called the "hard development" of mining and timber extraction and the "benevolent capitalis m" of tourist development, the dominant narratives of the abject Appalachian conveniently described rural conditions as a cultural pathology - as something that could be remedied through the 'civilizing forces' of industry.

Large-scale capitalist investment and industrial accumulation of mineral-rich land mostly occurred in the late 1800s (Eller 1982: 44-64). Industries entered the mountains "behind armies of resident and imported laborers who laid the tracks" for major rail systems, which eventually integrated the region into a network of main lines connecting major railroad hubs, such as Knoxville, to broader market systems (Lewis 1999: 3233). Prior to industrial development, however, the region was not as isolated or politically and economically 'backward' as the stereotypes suggest. In areas of eastern Kentucky, as Banks (1995: 331-332) describes, the economy prior to large-scale industrialization consisted of various scales of farming, commerce, and even local s mall-scale industries, based on timber and salt for example. In the early 1890s, however, tax records increasingly show the names of individual landowners being replaced by large corporations.

In some circumstances, landowners in more remote resource-rich areas sold property in the form of 'broad form deeds', which refers to the sale of the minerals underneath the land. This left surface areas (the taxable portions) of the land to the farmer, but under the condition that the underground portion would later be extracted. Landowners had very little understanding about the impacts and scale of these future extractions. Under these conditions, owners lost the richest resources on the land and mining - especially with the later development of surface mining - left surface areas unusable. Landowners lost millions of hectares of land through such transactions, which was facilitated by "obscure land titles, lost deeds, and poor records" in communities (Eller 1982: 55-57).

The process of consolidating land tracts took decades in some cases, as local and absentee investors navigated "the labyrinth of land titles and boundary lines" (Pudup 1995: 285). Local lawyers, elite land-andslave-owning entrepreneurs such as salt-makers, and other professionals with decision-making power and knowledge of land policies accrued additional wealth and power by accommodating the desires of northern capitalists and facilitating land transfers (Billings and Blee 2004: 27; Eller 1982: 57-58). Such accommodations, especially in contexts where governance systems were susceptible to "clientelism and corruption", paved the way for corporate investment throughout the region (Billings and Blee 2004). In some late $19^{\text {th }}$ century contexts, for example in newly formed West Virginia, the influx of industrial corporations led to transformations in property laws, with greater recognition of commercial and industrial use of land and waterways (Lewis 1998: 114-119). 
By the early 1900s, corporations controlled a large percentage of mountain lands and held significant decision-making power over economic diversity and the future of Appalachian development (Eller 1982: 5564). The ongoing enclosure and privatization of land to expand the coal economy has meant greater restrictions on use of 'the commons', which Hufford (2002: 102) notes, has supported "a patchwork" of socioeconomic strategies typical of rural areas, such as hunting, gathering, and other forms of relief and exchange rooted in accumulated knowledge systems of local ecologies. The symbolic and material power of the coal economy has devalued these strategies and created what Burke and Heynen (2014: 9) call a "knowledge hierarchy" where the value of coal supersedes other economies and valuations of the environment.

A collaborative land ownership study published in the early 1980s revealed the depths of corporate control of Appalachian resources. While the 20 million acres (8.1million ha) examined in the study were not entirely in the hands of 'absentee' owners, the study suggested that many of the large land-holding corporations that have the majority of mineral rights were subsidiaries of a few large, multinational energy companies (Eller 2008: 199-200). The shifts in land ownership have had long-term consequences. In 2010, 90 percent of West Virginia's coal production was in the hands of out-of-state owners (Richardson et al. 2014). As of 2013, in West Virginia, the top ten landowners in six counties (five of which are in the coalfields) own 50 percent of private land (Boettner 2013). A 2013 listening project conducted by members of Alliance for Appalachia found that people involved in economic diversification efforts in the region cite disparities in land ownership as a major barrier to economic transition (Taylor et al. 2014: 15).

\section{Social control, externalities, and unrest}

Interweaving forms of structural and symbolic violence also emerged through the systems of social control and dependency associated with the company towns of the coalfields, where companies owned the homes, stores, workplaces, and schools. Initially, the distance to Northern and Midwestern markets from the Appalachian coalfields posed challenges to owners and operators of the industry, but the highly controlled economy and labor market in mountain towns offset transportation costs (Williams 2002: 257-259). Company towns were certainly not restricted to the Appalachian region. Compared to other industrial contexts, however, a higher percentage of workers lived in company towns. According to Wagner and Obermiller (2011), over 20,000 company towns were built in Appalachia during the late $19^{\text {th }}$ and early $20^{\text {th }}$ centuries.

There were differences among company towns, but they were typically characterized by steep hierarchical relationships, especially during economic booms, creating an ownership class with monopolistic control over property and production, a class of small professionals and entrepreneurs, and a labor class, made up of locals and immigrants, positioned at the bottom rung of society (Gaventa 1980: 55-58). Towns were racially segregated and often tightly guarded by security or local police. Based on ideas of "scientific management" and couched in the language of "industrial betterment", they were designed to increase productivity and control over the workforce, while keeping out union organizers (Simon 1981: 172; Wagner and Obermiller 2011).

The settlement patterns of industrial elites and the managerial class - characterized by comfortable housing, sometimes along the hillsides overlooking the towns - symbolically reified these evolving paternalistic hierarchies (Eller 1982: 196). New developments, such as schools and stores, were sometimes given names associated with the owners of production, whereas workspaces retained local names. In the context of these growing disparities, the gospel of industrial modernism promised betterment through hard work. As the mountains became sites for industrial production and vacation spots for outside elites, displays of conspicuous consumption and leisure embellished the benefits accessible in the new industrial order (Gaventa 1980: 62-66). The "bonanza of modernization", according to Eller (1982: xxiv), "aroused aspirations, envies, and hopes."

As facilitators to the extractive industries to which they were politically and financially tied, the governing and managerial classes of coal towns prioritized their financial returns on natural resources over investment in social and infrastructural development (Eller 1982: 234), a common formula for structural violence. Gaventa (1980: 60-61) referred to these arrangements as the "political apparatus" - a system "of certain controls and biases that clearly served to benefit the political and economic elites more than they did the mountaineers or workers." Companies utilized their power to influence local and state government 
legislators to create or ignore laws and codes in ways that favored industry (Wagner and Obermiller 2011: 1929). Despite the decline of company towns during the Depression years, the coal industry maintains significant political sway in mining states and in traditionally coal-dependent areas.

Such political arrangements foster socially and ecologically violent economic processes that encourage profit maximization through the externalization of costs. When productivity gains in the coal economy, for example, are not used for improved safety measures or pollution prevention and clean-up, the costs fall on workers, communities, and taxpayers. Through the shifting of burdens, then, real costs are not reflected in the pricing of commodities, including fossil fuels (Donnaruma and Partyka 2012; Hahnel 2012). The Appalachian coal that has long fueled national energy demands has only been 'cheap' because there is no price signal that accounts for the true costs of pollution, degraded infrastructure, and unstable or hazardous environments. This is how Appalachia has subsidized the coal economy and why the region is frequently referred to as a national 'sacrifice zone.'

Regulatory agencies charged with supervising the economy are challenged with the arduous, if not impossible, task of accounting for its negative externalities. But externalities are unevenly dispersed and difficult to quantify, which too often results in inadequate corrective actions. Additionally, those who accrue financial benefits from externalization also tend to gain influence and power in regulatory decision-making (Donnaruma and Partyka 2012: 45). These political-economic arrangements have much to do with the production of vulnerability, hazards, and disasters in Appalachia's coal economy. These catastrophes are familiar - from the explosions, fires, and collapses in underground mines to the falling rocks and deadly rolling boulders in surface mines. Between 1902 and 1927, mine explosions occurred throughout Appalachia every year, killing over 2,400 people (CDC 2013; Eller 1982; MSHA 2012).

Mining is inherently dangerous and the new technologies of the $20^{\text {th }}$ century, such as mechanical hauling systems, electrical wiring, and cutting machines, produced new hazards. In his account of "normal accidents", defined as the inevitability of high-risk systems failing, Perrow (1984: 251) contends that coal mines provide "an unpredictable environment for humans." But the political-economic arrangements that encourage externalization on the one hand, and yet disempower regulatory efforts on the other, produce hazards that are indeed reducible and predictable. Too often, violence in the mines emerges from ineffective, underfunded, or inadequately enforced protective laws. Although mining codes and mine safety laws were present in all mining states by 1912, laws tended to emphasize personal responsibility. Inspections were infrequent and coroner's juries rarely held companies accountable for tragedies in the mines during the early decades of the $20^{\text {th }}$ century. It was not until the 1940s that the Bureau of Mines was given inspection authority (Eller 1982: 180-181). Despite the emergence of various state and federal laws and agencies concerned with mine health and safety since mid-century, preventable hazards persist.

For this reason, the United Mine Workers of America (UMWA) deemed the 2010 explosion that killed 29 miners at the Upper Big Branch mine of West Virginia an "industrial homicide" (UMWA 2011). The hazardous conditions contributing to the calamity, UMWA assert, represent "gross violations of mandatory health and safety standards." They were "not accidental", but rather the outcome of "a culture that demanded production at any cost" (UMWA 2011: 13). A 2014 study looking at twenty years of Department of Labor data and delinquency records found that thousands of mine operators not only fail to pay fines amassing from safety violations, but these delinquent mines tend to be more hazardous. Moreover, the report suggests that delinquent mines are still operating due to inadequate laws or lack of regulatory resources, even where they have penalties dating back years or even decades (Berkes 2014).

It is thus no surprise that the everyday slow violence of coal dust, repeatedly drifting into respiratory systems, continues to harm miners and mining communities. Among the various respiratory ailments associated with coal mining black lung disease, or pneumoconiosis, is especially debilitating. Historically, medical professionals and worker-compensation committees in coal states downplayed it. Compensation and treatment only emerged in the late 1960s and 1970s as a result of pressure from activists, disabled miners, and widows (Derickson 1983; Eller 2008; Smith 1981). The disease remains a serious problem in the region, however, taking hundreds of lives in recent decades, and even affecting young mine workers (Berkes 2012a, b; Eller 2008: 241-242; Hamby 2012; Ward 2012).

Miners and their communities have not stood by idly or accepted the violent conditions of mines and mining communities passively. The region's history of individual and collective resistance demonstrates this 
(Fisher 1993). Even in the face of legitimizing strategies and various forms of social control employed by coal operators "to prevent little hells", as one British-born coal operator once put it (Gaventa 1980: 67), compliance with the industrial order was not easily obtained. In West Virginia, for example, the Paint-Creek Cabin-Creek Strike of 1912, the Matewan Massacre of 1920, and the Battle of Blair Mountain of 1921 represent some of the bloodiest mining wars in the history of the region. In these contexts, it was not uncommon for corporate-government alliances to mobilize and employ a military force to quell uprisings (Williams 2002: 263-264), as happened during the five-day Battle of Blair Mountain, which is considered the largest armed insurrection in the United States since the Civil War (Biggers 2006: 157).

Historically, it was also not uncommon for the media to attribute the violence of coalfield rebellions to the untamed and feud-prone Appalachian, but with little to no insight into the political-economic dimensions that contributed to mining community struggles (Andreescu and Shutt 2009; Eller 1982; Fisher 1993). The aggression of the miner in these contexts was not "genetically induced or irrational", as Andreescu and Shutt (2009: 71) explain, but rather "the inevitable result of the working class struggle for political, social, and economic fairness." Returning to Žižek's (2008) analysis, labor uprisings in the coalfields must be historicized and understood as the visible outcome of deeply rooted subtle, slow, and systemic violence, as outlined above. Although miners made gains over the past century, increased mechanization, among other factors, has brought about new struggles and new forms of socio-ecological violence.

\section{More dynamite and destruction}

Around the middle of the $20^{\text {th }}$ century, significant changes occurred in the industry. Post-war negotiations between the United Mine Workers and coal companies resulted in union acceptance of mechanization in exchange for higher salaries and benefits for existing and retired miners (Williams 2002: 318). These negotiations, as well as technological change in deep mines, the emergence of surface mining, and shifts in the markets for coal, meant fewer mining jobs and declining union influence (Couto 1987). Mechanization in the form of surface mining rose in popularity as coal companies sought faster and cheaper means of extraction. The form of strip mining known as Mountaintop Removal (MTR) is extremely destructive, socially and ecologically: it emerged from the 1970s energy crisis (Figure 2). With mechanization, increased productivity, and declining employment came the increased concentration of mining operations into the hands of large corporations; thus creating greater distance between those with decision-making power in the industry and the communities in which they operate (Burns 2007: 4; Couto 1987; Eller 2008: 224).

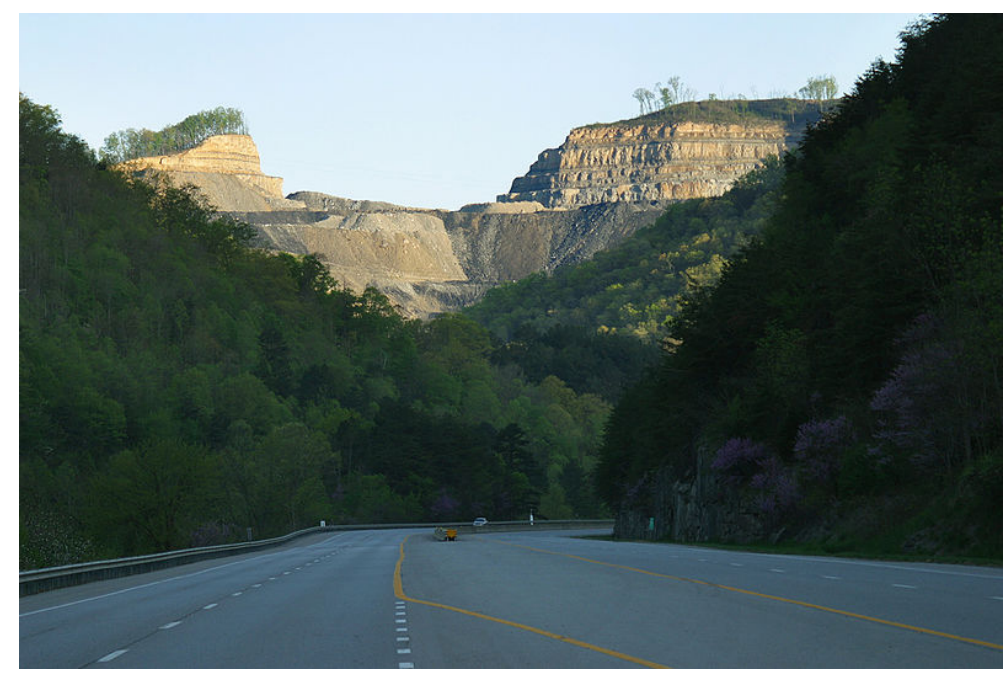

Figure 2: Mountaintop removal, Pike County, Kentucky. Source: Matt Wasson, Appalachian Voices. April 19th, 2010. CC BY 2.0 licence. 
MTR only employs a fraction of the workers once required for mining operations. In recent years, politicians and conservative media have employed a 'War on Coal' discourse to pin the loss of jobs in the coalfields on federal efforts to limit emissions at power plants. Omitted from this narrative, however, is one of the main culprits responsible for declining employment trends in the region: mechanization. Certainly emissions standards and the closure of coal power plants factor into shifts in the coal economy (McIlmo il and Hansen 2010: 3-16; Quest 2014); however, accord ing to economist Paul Krug man (2014), coal mining is "a job that was destroyed by technology long ago, with only a relative handful of workers -0.06 percent of the US work force - still engaged in mining."

The 'War' additionally fosters an ongoing 'jobs versus environment' dichotomy, which has been crippling for efforts to forge alliances between those concerned with job security and those concerned with the consequences of environmental degradation. This polarization has long haunted communities and recently culminated in dueling rallies at an EPA hearing on carbon emissions (Litvak and Hopey 2014). Bell and York (2010) expla in that industry-led campaigns, such as Friends of Coal, contribute to this polarization by attempting to maintain loyalties within communities and by cultivating a sense that coal is an inevitable part of daily life. Even in the context of "oppositional knowledge" to the destructive practices of industry, Billings (2008a: 25) notes that the "belief that nothing can be done" prevails as a result of the entrenched and hegemonic powers of the coal economy. The symbolic power of coal and the ideological strategies employed by politicians and the industry serve to obscure the violence of the coal economy and deny the possibility of alternatives. They overshadow the real, 'on-the-ground' economic transition efforts striving for economic and environmental justice in central mining regions (e.g. Brecher 2012; EKU 2013; KFTC 2014; Mills 2013; Solomon 2014; Taylor et al. 2014).

The drive to cut costs in coal production has significantly shaped human relationships with the biophysical world and there are, perhaps, no sites that better serve as evidence of this than a mountain that has been violently decapitated and reclaimed as a grassland, golf course, or business park. Hundreds of mountains in the region have been leveled over the past few decades, especially in West Virg inia, Kentucky, Virginia, and Tennessee (Epstein et al. 2011). These were part of some of the oldest mountain ecosystems in the world, house some of the highest levels of biodiversity in temperate climates, and give rise to the headwater streams for numerous major U.S. river systems. The blasting of mountain tops and dumping of overburden into valleys and streams scars landscapes permanently, and places a wide variety of aquatic and terrestrial species and their habitats at risk (Bernhardt and Palmer 2011).

Communities below MTR sites suffer the impacts of dynamite blasts and valley fills, which pollute valley streams and create unstable ground. The explosions cover residential areas with dust, destroy wells, and damage the foundation of homes (Burns 2007: 35; Epstein et al. 2011). Studies also show that communities living near MTR sites have elevated health problems and risks, including birth defects, cardiovascular disease, and cancer (Ahern et al. 2011; Esch and Hendry x 2011; Epstein et al. 2011; Hendry x 2013; Hitt and Hendry x 2010; Hendry x and Ahern 2009; Luanpitpong et al. 2014; Palmer et al. 2010; Zullig and Hendryx 2011).

A 2011 United States Geological Survey report stated that coal industries in the United States are the largest global consumers of explosives, with Kentucky and West Virginia being among the top three states (Apodaca 2013). The blasting can create loose material, or fly rock, on the mountaintop that ranges in size from small rocks to large boulders. Residents in the valleys below have experienced everything from softball size rocks landing in their yards to massive boulders rolling into communities, causing a wide range of damage, as well as displacement and death (Burns 2007: 35; Cooper 2009). In one incident in Virg inia during the summer of 2004, a boulder rolled into the bedroom of a three-year old boy and killed him as he slept in his bed (Cooper 2009).

Burns (2007: 57) divided community impacts of MTR into three stages. First, the community welcomes the mining company for the employment and tax opportunities. Second, community members become shocked at destructive practices of the company, although miners may remain loyal to it. At this point, out-migration begins. The company begins to buy homes, while some community members attempt to save their communities. During the final stage, massive buyouts and depopulation occur and the company increases its acreage. In this last stage, the community is largely abolished as businesses and schools close. Property values plummet. People lose their home insurance as the foundations of houses become unstable 
with cracked walls, floors, and ceilings. Water wells are destroyed. The area becomes prone to flooding due to the massive changes to ecosystems, and homes are frequently coated with layers of dust (Burns 2007: 5253).

In some instances, people refuse to sell their homes and they witness the decline of the community around them. Bulldozers penetrate the scene destroying not only physical structures, such as homes and cemeteries, but also the cultural and symbolic meanings embedded in them (Maples and East 2013). The social and environmental destruction of MTR produces refugees, mobile and immobile. It pushes people away from the land of their ancestors and their lifelong homes. Those who stay become what Nixon (2011: 19) refers to as "refugees in place" - a form of "displacement without moving." This process, he contends, "entails being immobilized and moved out of one's living knowledge as one's place loses its life-sustaining features." The violence of MTR is clear and has even prompted the United Nations Working Group on Business and Human Rights to call for investigations. Yet it is only now, after decades of devastation and destruction, that banks are beginning to pull funding for the practice (Sorkin 2015; Sturgis 2013).

\section{The curse of coal}

Appalachian scholars over the past several decades - influenced heavily by post-colonial development theories - have characterized coal-based 'modernization' in Appalachia as 'uneven', pointing to the politicaleconomic processes that have fostered "growth without development" (Eller 1982: 229) or, in the language of dependency theory, the "development of underdevelopment" (Simon 1981). Economic vulnerability in the region, as in areas historically impacted by the coal economy, has made Appalachia an ongoing target for top-down, federal relief and develop ment efforts, such as those associated with the Depression era Tennessee Valley Authority (TVA) and the 1960s War on Poverty offspring: the Appalachian Regional Commission (ARC). These efforts did lead to social programs and infrastructure improvements, but in some cases at great cost, as TVA's history of displacement illuminates (McDonald and Muldowny 1982). Additionally, federal and state development agencies continue to lean toward industrial recru itment and economic models based on competiveness and growth, with less attention to underlying structural problems (Billings 2008b:164; Davis 2012; Eller 2008:3).

Some researchers and activists concerned about Appalachian development have described the region as suffering from the 'resource curse', which - in contrast to modernization theory - posits that the abundance of natural resources can lead to negative development outcomes. While 'cursed' seems to be an apt characterization for parts of the region, much of the broader research on the resource curse has relied on oversimplified quantitative models for examining human-environmental relations (Pritchard 2013). The 'curse' in Appalachia is not simply the result of its resource wealth, but is best understood in relation to historical processes and multi-scalar structural arrangements that have shaped knowledge, power, and access and control over those resources. Multiple dimensions of socio-ecological violence, in other words, undergird the 'curse.'

\section{Violence beyond the mines}

The violence of mining, as extensive as it is, occurs at the early phases of coal's social life. As coal is removed from its womb in the mountains, it is then washed - often with chemicals - and prepared for transportation to sites of combustion, the crematoria of coal. It would appear, upon first glance, that the ash remains of coal are then laid to rest in landfills and impoundments, but closer examination reveals that coal ash is very mobile and has a social life of its own.

\section{Slurry floods and seeping contaminants}

In January of 2014, thousands of gallons of the chemical crude methylcyclohexyl methanol (MCHM) leaked into West Virginia's Elk River from storage tanks owned by Freedom Industries. The spill in itially left 300,000 residents without access to water supplies in and around Charleston. As a form of "slow violence" (Nixon 2011), it also led to hundreds of cases of illness and several hospitalizations from exposure (CDC 2015). An independent investigation by the Chemical Safety Board found the culprit to be two corrosive holes in the storage tanks, a result of inadequate inspection and self-policing (Trager and ChemistryWorld 
2014). Although the West Virginia governor attempted to distance this disaster from the coal industry, it turns out that MCHM is one of several chemicals used to remove impurities from coal prior to combustion (Parker 2014). Although there is insufficient information to determine the long-term health effects of MCHM and other coal processing chemicals, nineteen chemicals used for washing coal are known to cause cancer and twenty-four are connected to heart and lung damage (Epstein et al. 2011: 81).

Once the impurities are stripped, the leftover solid, liquid, or sludge-like waste, commonly referred to as 'slurry' or 'slag', is typically stored in impoundments, or sometimes in abandoned mines. Too often, slurry sites are located above valley communities, ensuring disaster if a pond is breached. This is precisely what happened at a Pittston Coal plant in Logan County, West Virginia in 1972. The largest slurry disaster in the US, known as the Buffalo Creek Flood, occurred when an earthen retaining wall collapsed. A giant wave of 132 million gallons (500 million liters) of black water rushed rapidly through the hollow. The water accumulated tons of debris in the flow, including cars, houses, and trailers. The flood killed 125 people and left thousands injured, traumatized, and displaced. A Pittston official explained that the pond was "incapable of holding the water God poured into it", suggesting the disaster was an "act of God" rather than the outcome of human fallacy. It emerged that by the 1970s, Pittston Coal had already accrued a record of safety violations, injuries, and fatalities (Bethell and McAteer 1972; Erikson 1976: 178; Schwarz-Barcott 2008).

Between 1972 and 2008, there have been over fifty slurry spills in Appalachia (Epstein et al. 2011: 81), including the 300 million gallon (1,136 million liter) slurry calamity in Martin County, Kentucky. In 2000, the Martin County Coal slurry impoundment located over an abandoned mine collapsed, sending sludge out the mine openings into nearby water systems, which affected property, aquatic life, and drinking water intakes. On top of dealing with the disaster itself, the impacted citizens also were forced to deal with a wide-range of post-disaster politics, which clearly illustrate how the regulatory apparatus was not impermeable to political influence. Industry-agency relations during recovery prioritized corporate interests and resulted in stymied investigations, whistleblower retaliation, inadequate space for public input, and an overall lack of transparency (Bingham 2005; McSpirit et al. 2005; UCS 2009).

While structural problems in impoundments and abandoned mines can lead to breakthroughs and blowouts in containment walls, slurry sites can also discharge wastewater and runoff slowly. In West Virginia, discolored and odorous drinking water in mining areas has led to multiple lawsuits against coal companies responsible for injecting slurry underground, but the large portion of slurry sites located in Appalachia (especially West Virginia and Kentucky) is cause for continuous concern about the safety of drinking water (CILIS 2015; Sewell 2012). Abrupt catastrophes and slow-seeping contamination are so commonplace in some mining areas that inadequate access to clean and safe drinking water has become a part of everyday life (Ghabra 2015).

\section{Harmful emissions}

When coal is transported to utility plants and is burned, its emissions compromise breathing, it slowly pois on bodies and environments, and it contributes to the climate crisis our planet now faces. This has been deemed a form of "social murder" by some (Singer 2014). The ill effects of air pollution from coal for humans and the environment has received considerable attention (Epstein et al. 2011; Evans 2010; CATF 2010; Lockwood 2012; Lockwood et al. 2009). Studies by the Clean Air Task Force point to the contribution of coal emissions to premature deaths and a number of health problems (CATF 2010). A 2012 report, Coal Blooded (Wilson et al. 2012), generated by civil rights, environmental, and indigenous organizations, reported that coal powered plants disproportionately impact communities of color and of low income. Although a 2015 study shows how new carbon standards proposed by the EPA could alter air quality in ways that produce immediate local and regional health benefits (Driscoll et al. 2015), renewable energy efforts face continuous obstacles from fossil fuel lobbyists, their political allies, and organizations attempting to undermine renewable energy mandates at the state level.

There are close to 500 power plants in the US, with most concentrated in the Midwest and in the Southeast. They are a leading contributor to the nation's $\mathrm{CO}_{2}$ emissions. A study tracing the waste and pollution generated from the lifecycle of coal (Epstein et al. 2011; EH\&E 2011) notes that of the total emissions of $\mathrm{CO}_{2}$ globally in 2005, coal contributed 41 percent. Due to its contribution to global climate change, Oxfam International issued a report prior to the 2015 G7 Summit in Germany referring to G7 coal 
powered plants as "a weapon of climate destruction" (Oxfam 2015). A reas of Appalachia also face challenges posted by broader air and climate issues. For example, the Great Smokey Mountains National Park and surrounding communities have been dealing with the damaging impacts of air pollution for decades and the Park experiences some of the highest levels of ozone exposure in the East (NPS 2015). To illustrate further, a study by the US Forest Service indicates that researchers are already observing responses to climate change in Appalachian forest systems and expect significant changes in temperatures, habitats, and precipitation over the next century (NRS 2015).

\section{Coal ash: the afterlife of coal}

Scrubber technologies used to reduce harmful emissions and accommodate clean air standards at coal power plants ironically contribute to another problem: coal ash (Castán Broto 2013). The toxic compounds that do not make their way into the air are stored in the form of either dry ash in landfills or wet ash in impoundments, which are similar in many ways to slurry impoundments and pose similar risks, as the recent coal ash disasters in Tennessee and North Carolina illustrate (Schaeffer et al. 2009). Approximately 45 'high hazard' impoundments exist in the US based on Environmental Protection Agency standards (EPA 2014). A high hazard rating means that failure in an impoundment wall could result in fata lities. Of the $45 \mathrm{high}$ hazard impoundments, nearly 20 are in the Southeast (SACE 2014). As one of the top waste streams in the country, over 100 million tons (91 million tonnes) of coal ash are produced in the US yearly (EPA 2015).

Coal ash contains a variety of harmful elements such as arsenic, mercury, and chro mium. It can move, sometimes slowly and invisibly, through air and water, posing risks to the health of humans and the environment. A number of studies have looked at water contamination issues at wet impoundments (Evans, Becher et al. 2011; Chatterjee 2009; Evans, Gottlieb, et al. 2011; Gottlieb et al. 2010; Kosson et al. 2008; Lukas 2010; Quarles and Segail 2010; Ruhl et al. 2010). More recent attention has been given to the risks of airborne coal ash particles. Ash in Lungs (Lockwood and Evans 2014), a study published by members of Physicians for Social Responsibility and Earthjustice, elaborates on the health risks of ingesting coal ash dust, specifically from exposure to the concentration of heavy metals within the dust particles. Additionally, the study found that of the 37 states generating coal ash, less than half require dust control at landfills, and Pennsylvania is the only state that requires dust control. Despite the attention recent coal ash disasters have drawn to the risks of coal ash, the EPA - after years of debates and delays in decision-making - declared coal ash a non-hazardous solid waste in December of 2014, leaving coal ash free from federal oversight and in the hands of state governments.

A brief look at the 2008 coal ash catastrophe at TVA's Kingston Fossil Plant in Roane County, Tennessee, illustrates not only the mobility of coal ash, but also how the violence of the coal economy persists after combustion. The TVA 'spill' involved a rapid avalanche of a billion gallons of ash sludge into surrounding neighborhoods and rivers. Fortunately there were no fatalities, but the spill quickly turned a river-side recreational and retirement community into an 'ash-scape' that took years to clean up as citizens dealt with plummeting property values and the an xiety of not knowing the long-term health consequences of living with ash. As with many of the disasters described above, inadequate management and oversight, as well as cost-cutting decision-making strategies, were among the proximate causes of the calamity (TVA 2009; Eldridge 2013).

The deeper, historical processes that produced this hazardous landscape, however, are connected to TVA's history of development in the Tennessee Valley. As a New Deal development agency created to "bring light" and rid the valley of its "pre-modern deficiency" (Hargrove 1994: 45; Wheeler 1986: 46), the TVA has been a part of life in the region for over half a century and the coal economy is intricately interwoven with TVA history. For those that have been around long enough, the TVA is associated with affordable electricity and jobs from, and loyalties to, the agency are common. When many Roane County residents passed by the ash impoundment sitting alongside the river, they trusted TVA and assumed it to be safe. To some, the impoundment had become an unquestioned part of the landscape, obscuring the threat that it posed (Eldridge 2013).

Through its effort to provide 'cheap' electricity, the TVA has played a significant role historically in fueling the violence of ext raction, contributing to the harmful emissions described above, and producing coal ash landscapes throughout the region. Although the agency began with hydroelectric power in 1933, within a 
couple of decades the Authority became one of the largest purchasers of coal in the nation. Today the agency purchases very little coal from Appalachia, but it was largely strip-mined coal from the mountains that powered the agency's first coal plants, including the Kingston Fossil Plant in Tennessee (Chandler 1984: 126; TVA 1965). Due to heavy reliance on coal by utility companies like the TVA and Duke Energy, the Southeast is now littered with leaking and hazardous coal ash impoundments (SACE 2014).

While reports in recent years suggest that impoundments at all 11 of TVA's coal plants have contaminated water sources (EIP 2013), the impacts of the 2008 disaster extend well beyond the confines of TVA sites. As part of the cleanup following the spill, four million tons (3.6 million tonnes) of coal ash were shipped by train to a landfill in a low-income, African A merican county in Alabama. Local officials deemed the storage of ash to be an economic opportunity as the county received about US\$1.00 per ton. According to environmental groups, funds from the landfill were spent in Perry County, but little of that in Uniontown, where the landfill resides. The dumping of ash, along with the dust, leaks, and run off from the landfill, has culminated into a civil rights complaint against the state of Alabama (Evans 2012; Moskowitz 2014). The social life of coal ash - with its avalanches, water and air contamination, and uneven distribution - clearly demonstrates how the slow and structural violence of the coal economy persists long after coal's incineration.

\section{Crises and possibilities}

The suffering and agony of the coal economy has not been shared equally throughout the nation, and the late mountain activist Judy Bonds understood this well. The daughter of a coal miner, Bonds was raised in Marfork Hollow, West Virg inia where her family lived for six generations until forced to evacuate due to the destructive impacts of MTR. Before her death in 2011, she summarized her thoughts on the destructive effects of the coal economy in an interview with Mother Jones (Makris 2003):

Appalachia is the sacrifice zone for America's so-called cheap energy. But it's not cheap. It costs a lot to clean up the messes of the coal companies ... Appalachians have been made expendable people. We've been made expendable people by the coal barons. I thin $\mathrm{k}$ the coal industry conspired to set the stereotype, and therefore make us expendable people so the rest of the country wouldn't care about Appalachia. People might think Appalachians are backwards, but only a stupid person dumps fill into clean water. The Appalachian forest is the lungs of the east coast.

Bonds' words capture much about the dimensions of violence imposed by the coal economy. Although coal, as an object, is not itself the purveyor of violence, examination of its social life illuminates the historical, socio-political, and economic processes that produce and reproduce multiple dimensions of violence. At the core of the destructive and uneven outcomes described above are the perverse economic incentives that push industries to externalize socio-ecological costs and the political arrangements that sustain and legitimize those uneven economic processes. The health outcomes, dispossession, displacement, and production of hazards and risk are not accidents. They are the result of political and economic decisionmaking processes that are largely inaccessible to those who suffer the adverse outcomes of those decisions. Gaventa's "political apparatus" of the industrial order has only intensified and expanded over the decades into the neoliberal era of corporate "super persons." The power accumulated by corporations over the past century, and especially in recent decades, gives them tremendous influence over political discourse and decision-making processes.

The coal economy is in crisis, on many levels. In Appalachian coal towns, coal is in decline and extraction is becoming increasingly unfeasible. In communities dealing with hazardous and toxic coal ash, utilities are under ever-increasing scrutiny. At broader national and global levels, the coal econo my is heavily and openly challenged for its contributions to climate change, leading to fossil fuel divestment campaigns among a variety of organizations and even national governments. The decline of the coal economy in the Appalachian Mountains is nonetheless the source of fear and hope among residents, and transition will undoubtedly be painful (Bailey 2013; Davis 2012; Haywood 2012; MACED 2013). In the midst of crises, however, possibilities emerge. As Burke and Shear (2014: 129) note, drawing on Gramsci, crises are not 
simply destructive, but they also destabilize discourses and social relations in ways that present new opportunities "beyond the conventional 'solutions."'

In an essay aimed at those feeling an xious about economic decline and the ecological crises our planet faces, Jensen (2013) suggests we "get apocalyptic." By apocalyptic, he means not "the end of the world", but rather from the Latin and Greek orig ins of the word "a lifting of the veil, the disclosure of something hidden." He asserts, "Once we've honestly faced the crises, then we can deal with what is ending-not all the world, but the systems that currently structure our lives." To become apocalyptic is to see clearly, to be honest about our planetary reality, and despite the seemingly overwhelming obstacles, to recommit to core values rooted in solidarity and justice. While there is often a tendency to conceptualize systemic change narrowly in terms of abstract 'revolution', Alperovitz (2011: 4-7) suggests that the social and economic pain of crisis often forces people to do new things and think in new ways, as evident in the creative wealth democratizing experiments that emerged out of de-industrialized Cleveland and Detroit.

In Appalachia, there has never been a shortage of creative economies operating under the radar or even in the shadows of the coal economy. Nor has there been a lack of grassroots efforts working toward alternatives beyond the traditional industrial mode of development (Gaventa et al. 1990). As briefly referenced above, there are currently promising economic transition collaborations among scholars, students, activists, and citizens occurring in the central mining areas of Appalachia, as well as 'beyond-coal' strategies throughout the broader region. The foci of some of these efforts include the development of 'bottom-up' democratic structures for policy-making (Taylor et al. 2014), the promotion of "natural assets" (EKU 2013), and youth-led initiatives to diversify the economy (Solomon 2014).

These projects may not constitute the grand revolution frequently called for by the critics of capitalis m, but they provide tremendous potential for not only improving livelihoods by attending to the pressing needs of communities, but also for strengthening networks and values pivotal to renewed humanenvironmental relationships and the development of more egalitarian and sustainable futures. In contrast to the dominant narratives of capitalist modernity, change is not unidirectional, and as Reece (2011) pointed out as he pondered lessons learned from the writer Wendell Berry, progress "doesn't always look like progress." Rather, in the context of the multiple crises we now face, he continues, progress "might look more like a family farm, powered by sunlight."

\section{References}

Ahern, M.M., M. Hendryx, J. Conley, E. Fedorko, A. Ducatman, and K.J. Zullig. 2011. The association between mountaintop mining and birth defects among live births in central Appalachia, 1996-2003. Environmental Research 111:838-846.

Alperovitz, G. 2011. America beyond capitalism: reclaiming our wealth, our liberty, and our democracy. Takoma Park, MD: Democracy Collaborative Press.

Andreescu, V., and J.E. Shutt. 2009. Violent Appalachia: the media's role in the creation and perpetuation of an American myth. The Journal of the Institute of Justice and International Studies 9:62-75.

Apodaca, L.E. 2013. USGS 2011 minerals yearbook: Explosives [advance release]. US Geological Survey. [accessed June 2015].

ARC. 2009. Subregions in Appalachia. Appalachian Regional Commission. November, 2009.

http://www.arc.gov/research/MapsofAppalachia.asp?MAP ID=31

Bailey, J. 2013. Speak yourpiece: why regions fail. Daily Yonder, January 14.

Bankoff, G. 2004. The historical geography of disaster: 'vulnerability' and 'local knowledge' in Western discourse. In Bankoff G., G. Frerks and D. Hilhorst (eds.) Mapping vulnerability: disasters, development, and people. London: Earthscan. Pp. 25-36.

Banks, A. 1995. Class formation in the southeastern Kentucky coalfields, 1890-1920. In M.B. Pudup, D.B. Billings and A.L. Waller (eds.) Appalachia in the making: the mountain south in the nineteenth century. Chapel Hill: University of North Carolina Press. Pp. 321-346.

Beaver, P.D. 1988. Appalachian cultural systems, past and present. In S.E. Keefe (ed.) Appalachian mental health. Lexington: The University Press of Kentucky. Pp. 15-23. 
Bell, S.E., and R. York. 2010. Community economic identity: the coal industry and ideology construction in West Virginia. Rural Sociology 75 (1):111-143.

Berkes, H. 2012a. As mine protections fail, black lung cases surge. National Public Radio, July 9. [accessed June 2015].

Berkes, H. 2012b. Republican lawmakers seek to block funding on black lung regulation. National Public Radio, July 17. [accessed June 2015].

Berkes, H. 2014. Coal mines keep operating despite in juries, violations and millions in fines. National Public Radio, November 12. [accessed June 2015].

Bernhardt, E.S., and M.A. Palmer. 2011. The environmental costs of mountaintop mining valley fill operations for aquatic ecosystems of the central Appalachians. Annals of the New York Academy of Sciences 1223:39-57.

Bethell, T.N., and D. McAteer. 1972. The Pittston mentality: manslaughter on Buffalo Creek. Washington Monthly, May.

Biggers, J. 2006. The United States of Appalachia: How southern mountaineers brought independence, culture, and enlightenment to America. Emeryville, CA: Shoemaker and Hoard.

Billings, D.B. 2008a. "Conscious hearts" and oppositional knowledge in the struggle against mountaintop removal coal mining. Journal of Appalachian Studies 14 (1/2):20-27.

Billings, D.B. 2008b. Economic representations in an American region: what's at stake in Appalachia. In D.F. Ruccio (eds.) Economic representations: academic and everyday. London: Routledge. Pp. 156-169.

Billings, D.B., and K. Blee. 2004. Social origins of Appalachian poverty: markets, cultural strategies, and the state in an Appalachian Kentucky community, 1804-1940. Rethinking Marxism 16 (1):19-36.

Bingham, C. 2005. Under mined. Washington Monthly, January/February.

Boettner, T. 2013. Who owns West Virgin ia in the 21st century? West Virg inia Center on Budget and Policy, December 9. [accessed June 2015].

Bourdieu, P. 1991. Language and symbolic power. Cambridge and Malden: Polity Press.

Bourdieu, P., and L. Wacquant. 2004. Symbolic violence. In N. Scheper-Huhes and P. Bourgois (eds.) Violence in war and peace: an anthology. Malden: Blackwell Publishing. Pp. 272-274.

Bourgois, P. 2009. Recognizing invisible violence: a thirty year retrospective. In B. Rylko-Bauer, L. Whiteford and P. Farmer (eds.) Global health in times of violence. Santa Fe: School of Advanced Research Press. Pp. 17-40.

Brecher, J. 2012. Jobs beyond coal: a manual for communities, workers, and environmentalists. Labor Network For Sustainability.

Burke, B., and B. Shear. 2014. Introduction: engaged scholarship for non-capitalist political ecologies. Journal of Political Ecology 21:127.

Burke, B.J., and N. Heynen. 2014. Transforming participatory science into socioecological praxis: valuing marginalized environmental knowledges in the face of the neoliberalization of nature and science. Environment and Society: Advances in Research 5:7-27.

Burns, S.S. 2007. Bringing down the mountains: the impact of mountaintop removal on southern West Virginia communities. Morgantown: West Virginia University Press.

Castán Broto, V. 2013. Employment, environmental pollution and working class life in Tuzla, Bosnia and Herzegovina. Journal of Political Ecology 20: 1-13.

CATF. 2010. The toll from coal. Clean Air Task Force.

Cavender, A. 2003. Folk medicine in southern Appalachia. Chapel Hill: University of North Carolina Press.

CDC. 2013. Office of Mine Safety and Health Research: coal mining disasters:1839 to present. Center for Disease Control. [accessed May 2015].

http://www.cdc.gov/niosh/mining/statistics/content/coaldis asters.html.

CDC. 2015. 2014 West Virginia chemical release. Centers for Disease Control and Prevention. [accessed June 2015]. http://emergency.cdc.gov/chemical/MCHM/westvirginia2014/. 
Chandler, W.U. 1984. The myth of the TVA: conservation and development in the Tennessee Valley, 19331983. Cambridge, MA: Ballinger Publishing Company.

Chatterjee, R. 2009. Coal-ash spills highlight ongoing risk to ecosystems. Environmental Science and Technology 43(9): 3003-3004.

CILIS. 2015. Coal Impoundment Location and Information System. [accessed June 2015]. http://www.coalimpoundment.org/default.asp

Cooper, D. 2009. Boulder from mountaintop coal mining s mashes into Kentucky home. The Huffington Post, September 9.

Couto, R. 1987. Changing technologies and consequences for labor in coal mining. In D.B. Cornfield (ed.) Workers, managers, and technological change: emerging patterns of labor relations. New York: Springer. Pp.175-202.

Davis, D. 2012. Speak your piece: living in the fixer-upper. Daily Yonder, October 29.

Derickson, A. 1983. Down solid: the origins and development of black lung insurgency. Journal of Public Health Policy 4 (1):22-44.

Donnaruma, C., and N. Partyka. 2012. Challenging the presumption in favor of markets. Review of Radical Political Economics 44 (1):40-61.

Driscoll, C.T., J.J. Buonocore, J.I. Levy, K.F. Lambert, S.B. Burtraw, H. Fakhraei, and J. Schwartz. 2015. US power plant carbon standards and clean air and health co-benefits. Nature Climate Change 5:535-540.

EH\&E. 2011. Emissions of hazardous air pollutants from coal-fired power plants. Environmental Health \& Engineering, Inc. Report for American Lung Association.

EIP. 2013. Five years after Kingston spill TVA records show groundwater contamination at all 11 coal plants. Environmental Integrity Project. [accessed June 2015]. http://www.environmentalintegrity.org/news reports/11 07 2013.php

EKU. 2013. Students, faculty helping Elkorn City become certified "trail town." Eastern Kentucky University. [accessed June 2015]. http://www.eku.edu/news/students-faculty-helping-elkhorn-citybecome-certified-trail-town .

Eldridge, E.R. 2013. The TVA coal ash disaster and the coal calamity contiuum in southern Appalachia. Ph.D. dissertation. Knoxville, USA: University of Tennessee.

Eller, R.D. 1982. Miners, millands, and mountaineers: industrialization of the Appalachian South, 18801930. Knoxville: The University of Tennessee Press.

Eller, R.D. 2008. Uneven ground: Appalachia since 1945. Lexington: The University Press of Kentucky.

EPA. 2014. Coal combustion residues (CCR) - surface impoundments with high hazard potential ratings. US Environmental Protection Agency. [accessed June 2015]. http://www.epa.gov/osw/nonhaz/industrial/special/fossil/ccrs-fs/index.htm.

EPA. 2015. Frequent questions about the coal ash disposal rule. US Environmental Protection Agency. [accessed August 2015]. http://www2.epa.gov/coalash/frequent-questions-about-coal-ash-disposal$\underline{\text { rule }}$

Epstein, P.R., J.J. Buonocore, K. Eckerle, M. Hendry x, B.M.I. Stout, R. Heinberg, R.W. Clapp, B. May, N.L. Reinhart, M.M. Ahern, S.K. Doshi, and L. Glustrom. 2011. Full cost accounting for the life cycle of coal. Annals of the New York Academy of Sciences 1219:73-98.

Erikson, K.T. 1976. Everything in its path: destruction of community in the Buffalo Creek flood. New York: Simon and Schuster.

Esch, L., and M. Hendryx. 2011. Chronic cardiovascular disease mortality in mountaintop mining areas of central Appalachian states. Journal of Rural Health 27:350-357.

Evans, B. 2012. Alabama's blackbelt region: a land forgotten, contaminated by coal ash. Physicians For Social Responsibility.

Evans, L. 2010. Failing the test: the unintended consequences of controlling hazardous air pollution from coal-fired power plants. Earthjustice. 
Evans, L., M. Becher, and B. Lee. 2011. State of failure: how states fail to protect our health and drinking water from toxic coal ash. Earthjustice and Appalachian Mountain Advocates.

Evans, L., B. Gottlieb, L. Widawsky, J. Stant, A. Russ, and J. Dawes. 2011. EPA's blind spot: hexavalent chromium in coal ash. Earthjustice, Physicians for Social Responsibility, and Environmental Integrity Project.

Farmer, P. 2004. On suffering and structural violence: a view from below. In N. Scheper-Hughes and P. Bourgois (eds.) Violence in war and peace: an anthology. Malden: Blackwell Publishing. Pp.281-289.

Ferguson, J. 2009. The uses of neoliberalism. Antipode 41 (S1):166-184.

Fisher, S.L., ed. 1993. Fighting back in Appalachia: traditions of resistance and change. Philadelphia: Temple University Press.

Foster, J.B., and H. Holleman. 2012. Weber and the environment: classical foundations for a postexemptionalist sociology.American Journal of Sociology 117 (6):1625-1673.

Freese, B. 2004. Coal: a human history. New York: Penguin Books.

Galtung, J. 1969. Violence, peace, and peace research. Journal of Peace Research 6 (3):167-191.

Gaventa, J. 1980. Power and powerlessness: quiescence and rebellion in an Appalachian valley. Urbana and Chicago: University of Illinois Press.

Gaventa, J., B.E. Smith, and A. Willingham (eds.). 1990. Communities in economic crisis: Appalachia and the South. Philadelphia: Temple University Press.

Geller, P. (dir.). 2009. Coal country [motion picture]. Evening Star Productions.

Ghabra, O. 2015. After the spill: life in West Virginia's coal country. The Atlantic, January 9.

Gottlieb, B., S.G. Gilbert, and L.G. Evans. 2010. Coal ash: the toxic threat to our health and environment. Physicians for Social Responsiblity and Earthjustice.

Hahnel, R. 2012. The growth imperative: beyond assuming conclusions. Review of Radical Political Economics 45 (1):24-41.

Hall, S. 1997. The spectacle of the 'other.' In S. Hall (ed.) Representation: cultural representations and signifying practices. London: SAGE. Pp.223-290.

Hamby, C. 2012. Black lung surges back in coal country. The Center for Public Integrity.

Hargrove, E.C. 1994. Prisoners of myth: the leadership of the Tennessee Valley Authority, 1933-1990. Princeton: Princeton University Press.

Harrington, M. 1962. The other America: poverty in the United States. Baltimore: Penguin Books.

Haywood, K.B. 2012. New risk takers design a post-coaleconomy. Daily Yonder, November 27.

Hendry x, M. 2013. Personal and family health in rural areas of Kentucky with and without mountaintop coal mining. Journal of Rural Health 29(s1):s79-s88.

Hendryx, M., and M.M. Ahern. 2009. Mortality in Appalachain coal mining regions: the value of statistical life lost. Public Health Reports 124 (July-August):541-550.

Hitt, N., and M. Hendryx. 2010. Ecological integrity of stream related to human cancer mortality rates. EcoHealth 7:91-104.

Hufford, M. 2002. Reclaiming the commons: narratives of progress, preservation, and Ginseng. B.J. Howell (ed.) Culture, environment, and conservation in the Appalachian South. Urbana and Chicago: University of Illinois Press. Pp.100-120.

Jarosz, L., and V. Lawson. 2002. "Sophisticated people versus rednecks": economic restructuring and class difference in America's West.Antipode:34(1):8-27.

Jensen, R. 2013. Get apocalyptic: why radical is the new normal. Yes!Magazine, May 24.

KFTC. 2014. What do we mean by a just transition for Appalachia?. Kentuckians For the Commonwealth. [accessed June 2015]. http://kftc.org/issues/what-do-we-mean-just-transition-appalachia.

Kopytoff, I. 1986. The cultural biography of things: commoditization as process. In A. Appadurai (ed.) The social life of things: commodities in cultural perspective. Cambridge: Cambridge University Press. Pp.64-94. 
Kosson, D.S., F. Sanchez, P. Kariher, L.H. Turner, R. Delapp, and P. Seignett. 2008. Characterization of coal combustion residues from electric utilities - leaching and characterization data. Environmental Protection Agency.

Krugman, P. 2014. The war on coal already happened. The New York Times, June 7.

Ledford, K. 1999. Landscape and a people set apart: narratives of exploration and travel in early Appalachia. In D.B. Billings, G. Norman and K. Ledford (eds.) Back talk from Appalachia: confronting stereotypes. Lexington: The University Press of Kentucky. Pp. 47-66.

Lewis, R.L. 1998. Transforming the Appalachian countryside: railroads, deforestation, and social change in West Virginia, 1880-1920: Chapel Hill: The University of North Carolina Press.

Lewis, R.L. 1999. Beyond isolation and homogeneity: diversity and the history of Appalachia. In D.B. Billings, G. Norman and K. Ledford (eds.) Back talk from Appalachia: confronting stereotypes. Lexington: The University of Kentucky Press. Pp. 21-43.

Litvak, A., and D. Hopey. 2014. Dueling rallies pit jobs against air. Pittsburgh Post-Gazette, August 1.

Lockwood, A.H. 2012. The silent epidemic: coal and the hidden threat to health. Cambridge, MA: MIT Press.

Lockwood, A.H., and L. Evans. 2014. Ash in lungs: how breathing coal ash is hazardous to your health. Physicians For Social Responsibility and Earthjustice.

Lockwood, A.H., K. Welker-Hood, M. Rauch, and B. Gottlieb. 2009. Coal's assault on human health: a report from physicians for social responsibility. Physicians For Social Responsibility.

Luanpitpong, S., M. Chen, T. Knuckles, S. Wen, J. Luo, E. Ellis, M. Hendry x, and Y. Rojanasakul. 2014. Appalachian mountaintop mining particulate matter induces neoplastic transformation of human bronchial epithelial cells and promotes tumor formation. Environmental Science and Technology 48 (21):12912. correction

Lukas, T. 2010. Duke scientists look deeper for coal ash hazards. Duke Today, November 29.

MACED. 2013. Staggering job loss in eastern Kentucky coal industry intensifies need for economic change. Mountain Association for Community Economic Development.

Makris, N. 2003. A coal miner's daughter. Mother Jones, January 16.

Maples, J.N., and E.A. East. 2013. Destroying mountains, destroying cemeteries: historic mountain cemeteries in the coalfields of Boone, Kanawha, and Raleigh counties, West Virginia. Journal of Appalachian Studies 19 (1 \& 2).

McDonald, M.J., and J. Muldowny. 1982. TVA and the dispossessed. Kno xville: The University of Tennessee Press.

McIlmoil, R., and E. Hansen. 2010. The decline of central Appalachian coal and the need for economic diversification. White Paper No. 1. Downstream Strategies.

McSpirit, S., S.L. Scott, S. Hardesty, and R. Welch. 2005. EPA actions in post disaster Martin County, Kentucky: an analysis of bureaucratic slippage and agency recreancy. Journal of Appalachian Studies: 30-65.

Mills, A. 2013. Imagining a post-coal Appalachia. CoLab Radio, April 23.

Moskowitz, P. 2014. A labama community alleges race bias over toxic landfill site. Al Jazeera America, August 22.

MSHA. 2012. Historical data on mine disasters in the United States. Mine Safety and Health Administration.

Nixon, R. 2011. Introduction. In R. Nixon (ed.) Slow violence and the environmentalism of the poor. Cambridge, MA: Harvard University Press. Pp.1-44.

NPS. 2015. Air quality. National Park Service: Great Smoky Mountains. [accessed July 2015]. http://www.nps.gov/grsm/learn/nature/air-quality.htm

NRS. 2015. Publications \& data: central Appalachian forest ecosystem vulnerability assessment and synthesis. Northern Research Station, Forest Service, USDA. [accessed June 2015]. http://www.nrs.fs.fed.us/pubs/47885 
Oliver-Smith, A. 2004. Theorizing vulnerability in a globalized world: a political ecological perspective. In Bankoff G., G. Frerks and D. Hilhorst (eds.) Mapping vulnerability: disasters, development, and people. London: Earthscan. Pp.10-24.

Oxfam. 2015. Let them eat coal: why the G7 must stop burning coal to tackle climate change and fight hunger. Oxfam Briefing Paper.

Palmer, M.A., E.S. Bernhardt, W.H. Schlesinger, K.N. Eshleman, E. Foufoula-Georg iou, M.S. Hendryx, A.D. Lemly, G.E. Likens, O.L. Loucks, M.E. Power, P.S. White, and P.R. Wilcock. 2010. Mountaintop mining consequences. Science 327 (January 8):148-149.

Parker, L. 2014. A century of controversy, accidents in West Virginia's chemical valley in lead-up to spill. National Geographic, January 18.

Peluso, N.L., and M.J. Watts. 2001. Violent environments. In N.L. Peluso and M. Watts (eds.) Violent environments. Ithaca: Cornell University Press. Pp.3-38.

Perrow, C. 1984. Normal accidents: living with high-risk technologies. New York: Basic Books.

Powell, K.M. 2007. The anguish of displacement: the politics of literacy in the letters of mountain families in Shenandoah National Park. Charlottesville: Virginia University Press.

Pritchard, M. 2013. Re-inserting and re-politicizing nature: the resource curse and human-environment relations. Journal of Political Ecology 20: 361-375.

Pudup, M.B. 1995. Town and country in the transformation of Appalachian Kentucky. In M.B. Pudup, D.B. Billings and A.L. Waller (eds.) Appalachia in the making: the mountain South in the nineteenth century. Chapel Hill: The University of North Carolina Press. Pp. 270-296.

Pudup, M.B., D.B. Billings, and A.L. Waller (eds.). 1995. Appalachia in the making: the mountain South in the nineteenth century. Chapel Hill: The University of North Carolina Press.

Quarles, M., and C. Segail. 2010. Slow motion spills: coal combustion waste and water in Kentucky. Sierra Club, Kentucky Waterways Alliance, and Global Environmental, LLC.

Quest, S. 2014. Surging coal imports: Appalachian coal miners to lose out. Bidness Etc., August 15.

Reece, E. 2011. Wendell Berry's wild spirit. Garden \& Gun, August/September.

Rehder, J.B. 2004. Appalachian folkways. Baltimore: Johns Hopkins University Press.

Richardson, L., R. Cleetus, S. Clemmer, and J. Dyette. 2014. Economic impacts on West Virginia from projected future coal production and implications for policy makers. Environmental Research Letters 9:1-9.

Ruhl, L., A. Vengosh, G. S. Dwyer, H. Hsu-Kim, and A. Deonarine. 2010. Environmental impacts of the coal ash spill in Kingston, Tennessee: an 18-month survey. Environmental Science and Technology 44: 9272-9278.

SACE. 2014. Southeast coal ash waste. Southern Alliance for Clean Energy. [accessed October 2014]. http://www.southeastcoalash.org/.

Sarnoff, S. 2003. Central Appalachia - still the other America. Journal of Poverty 7 (1/2):123-139.

Schaeffer, E., L. Evans, and L. Widawsky. 2009. Coming clean: what the EPA knows about the dangers of coal ash. Environmental Integrity Project and Earthjustice.

Scheper-Hughes, N., and P. Bourgois (eds.). 2004. Violence in war and peace: an anthology. Malden: Blackwell Publishing.

Schwarz-Barcott, T.P. 2008. After the disaster: re-creating communnity and well-being at Buffalo Creek since the notorious coal-mining disaster in 1972. Amherst: Cambria Press.

Sewell, B. 2012. Buried blackwater: revealing coal's dirty secret. Appalachian Voices, August 8.

Simon, R.M. 1981. Uneven development and the case of West Virg inia: going beyond the colonialism model. Appalachian Journal 8(3):165-186.

Singer, M. 2014. Climate change and social murder. Anthropology News (July).

Smith, B.E. 1981. Black lung: the social production of disease. International Journal of Health Services 11 (3): 343-359. 
Solomon, J. 2014. These young people are pioneering Appalachia's post-coal economy. Yes! Magazine, July 17.

Sorkin, A.R. 2015. A new tack in the war on mining mountains. The New York Times, March 9.

Sturgis, S. 2013. UN human rights group calls for investigation of mountaintop removal mining in Appalachia. The Institute for Southern Studies, May 2.

Swartz, D. 1997. Culture and power: the sociology of Pierre Bourdieu. Chicago: University of Chicago Press.

Taylor, B., D. Taylor, B. Price, and A. Munn. 2014. Economic transition in central Appalachia: knowledge/power mapping for bottom-up policy. Practicing Anthropology 36 (4):13.

Trager, R., and ChemistryWorld. 2014. Cause found for large chemical spill in West Virginia. Scientific American, July 25.

TVA. 1965. The Kingston steam plant: a report on the planning, design, construction, costs, and first power operations. Technical Report No. 34. Tennessee Valley Authority.

TVA. 2009. Inspection report: review of the Kingston fossil plant ash spill root cause study and observations about ash management. Tennessee Valley Authority, Office of Inspector General 2008-12283-02, July 23.

UCS. 2009. Coal slurry spill investigation suppressed. Union of Concerned Scientists. [accessed June 2015]. http://www.ucsusa.org/scientific integrity/abuses of science/coal-slurry-spill.html.

UMWA. 2011. Industrial homicide: report on the Upper Big Branch mine disaster. United Mine Workers of America.

Wagner, T.E., and P.J. Obermiller. 2011. A double-edged sword: social control in Appalachian company towns. S.D. Brunn (ed.) Engineering Earth. London and New York: Springer. Pp.1917-1935.

Ward, K.J. 2012. GOP budget move stalls black lung plan. The Center for Public Integrity.

Weaver, B.J. 1996. What to do with the mountain people? In J.G. Cantrill and C.L. Oravec (eds.) The symbolic Earth: discourse and our creation of the environment. Lexington: The University of Kentucky Press. Pp. 151-175.

Wheeler, W.B. 1986. TVA and the Tellico dam, 1936-1979: a bureaucratic crisis in post-industrial America. Knoxville: The University of Tennessee Press.

Williams, J.A. 2002. Appalachia: a history: The University of North Carolina Press.

Wilson, A., J. Patterson, K. Fink, K. Wasserman, A. Starbuck, A. Sartor, J. Hatcher, and J. Fleming. 2012. Coal blooded: putting profits before people. NAACP, Indigenous Environmental Network, Little Village Environmental Justice Organization.

Žižek, S. 2008. Violence: six sideways reflections. New York: Picador.

Zullig, K.J., and M. Hendryx. 2011. Health-related quality of life among central Appalachian residents in mountaintop mining counties. American Journal of Public Health 101 (5): 848-853. 